\title{
Hubungan Harga Diri dan Prasangka Gender Dengan Kecenderungan Perilaku Cyberbullying Pelajar Jakarta
}

\author{
Teguh Lesmana; Febrianto \\ Universitas Bunda Mulia \\ J1. Lodan Raya No 2, Jakarta Utara, Ancol \\ Teguhlesmana73@gmail.com
}

(C2019 -JPT Fakultas Psikologi Universitas Negeri Makassar. Ini adalah artikel dengan akses terbuka di bawah licenci CC BY-NC-4.0 (https://creativecommons.org/licenses/by-nc/4.0/)

\begin{abstract}
The phenomenon of cyberbullying often occurs in Indonesia, especially in adolescents. The case of cyberbullying tends to occur because of the problem of self-esteem in the perpetrators of cyberbullying. Apart from self-esteem issues, it was also found that men tend to do cyberbullying more often than women. The purpose of this study was to determine the relationship of self-esteem and gender prejudice to cyberbullying behavior on students in Jakarta. The research method used is the stratified random sampling technique. This research was conducted to high school and vocational high school students on an equal level in DKI Jakarta with a sample of 435 people. The results of this study indicate that there is a significant relationship between selfesteem and the tendency of cyberbullying behavior. In addition, gender prejudice was also found to have a significant relationship with the tendency of cyberbullying behavior. These results are expected to be the basis for educators and parents and the government to provide early education to adolescents about the importance of developing tolerance and respect for the opposite sex and providing education on how to use social media wisely.
\end{abstract}

Keywords: Self-esteem, gender prejudice, cyberbullying.

\begin{abstract}
Abstrak. Fenomena cyberbullying sering terjadi di Indonesia, terutama pada remaja. Kasus cyberbullying cenderung terjadi karena masalah harga diri pada pelaku cyberbullying. Terlepas dari masalah harga diri, ditemukan juga bahwa pria cenderung melakukan cyberbullying lebih sering daripada wanita. Tujuan dari penelitian ini adalah untuk mengetahui hubungan harga diri dan prasangka gender dengan perilaku cyberbullying pada siswa di Jakarta. Metode penelitian yang digunakan adalah teknik stratified random sampling. Penelitian ini dilakukan untuk siswa sekolah menengah dan kejuruan pada tingkat yang sama di DKI Jakarta dengan sampel 435 orang. Hasil penelitian ini menunjukkan bahwa ada hubungan yang signifikan antara harga diri dan kecenderungan perilaku cyberbullying. Selain itu, prasangka gender juga ditemukan memiliki hubungan yang signifikan dengan kecenderungan perilaku cyberbullying. Hasil ini diharapkan menjadi dasar bagi pendidik dan orang tua dan pemerintah untuk memberikan pendidikan awal kepada remaja tentang pentingnya mengembangkan toleransi dan menghormati lawan jenis dan memberikan pendidikan tentang cara menggunakan media sosial secara bijak.
\end{abstract}

Kata Kunci: harga diri, prasangka Gender, cyberbullying 


\section{PENDAHULUAN}

Penggunaan internet menjadi populer di kalangan remaja. Handphone dan internet memudahkan para penggunanya untuk berkomunikasi. Mereka tidak harus bertemu tatap muka secara langsung untuk dapat berkomunikasi karena mereka dapat melakukannya dari jarak jauh (Lenhart, 2015). Berdasarkan penelitian yang dilakukan oleh UNICEF Indonesia, 80\% remaja mengunakan internet untuk mencari data dan informasi khususnya yang berkaitan dengan tugas-tugas sekolah. Sedangkan, $70 \%$ menggunakan internet untuk bertemu teman online melalui media sosial, dan $65 \%$ menggunakan internet untuk mengakses musik. Dari penelitian yang sama, disebutkan bahwa remaja juga mengakses internet setiap hari atau setidaknya seminggu sekali (Razak, 2014).

Remaja dapat mengakses berbagai informasi yang dibutuhkan dengan adanya internet. Selain itu, remaja juga dapat mengakses berbagai situs termasuk media sosial. Situs media sosial online, seperti chatting membuat seseorang dapat berkomunikasi dengan siapapun, kapanpun dan dimanapun (Lenhart, 2015). Sayangnya, internet dan media sosial online tidak hanya digunakan sebagai media pembelajaran dan komunikasi namun juga sebagai sarana untuk melakukan cyberbullying. Berdasarkan penelitian yang dilakukan oleh kementrian komunikasi yang didukung oleh UNICEF (Razak, 2014) pada remaja usia 10 sampai 19 tahun dengan populasi besar dari 43,5 juta anak-anak dan remaja, ditemukan bahwa $42 \%$ remaja memiliki resiko ditindas secara online dan $13 \%$ diantaranya telah menjadi korban cyberbullying yang artinya ada sekitar 5.655.000 remaja yang telah menjadi korban cyberbullying sejak tahun 2014. Selain itu, survei dari Kementrian Sosial (Laksana, 2017) juga menyebutkan bahwa ada $84 \%$ kasus bullying yang sebagian besar merupakan cyberbullying. Kasus tersebut terjadi pada remaja yang ditemukan di Indonesia namun, data tersebut belum termasuk dengan kasus yang tidak dilaporkan.

Berdasarkan penelitian yang dilakukan oleh Yayasan Semai Jiwa Aini (dalam Juwita dan Kustanti, 2012) terdapat tiga kota yang memiliki Rudman \& Meschler dalam kasus bullying tertinggi di Indonesia yaitu di Yogyakarta, Jakarta, dan Surabaya. Sejalan dengan hal itu kota Jakarta juga termasuk sebagai kota yang memiliki kasus cyberbullying yang tinggi. Hal ini didukung oleh penelitian yang dilakukan oleh Komalasari, Nabilah, dan Wahyuni (2012) terhadap 360 siswa SMA di DKI Jakarta yang menemukan bahwa $34.4 \%$ siswa pernah mengalami bullying dan $28.4 \%$ diantaranya merupakan korban cyberbullying. Pengalaman menjadi korban cyberbullying yang paling banyak dialami oleh siswa adalah melalui website. Sebanyak $22.6 \%$ siswa mengalaminya di lingkungan sekolah dan $21.5 \%$ mengalaminya di luar lingkungan sekolah.

Pecino dan Duran (2016) menjelaskan bahwa meskipun perbedaan gender tidak konsisten dalam perilaku cyberbullying namun, seperti sama halnya dalam kekerasan tradisional terhadap perempuan beberapa penelitian juga melaporkan bahwa kejahatan cyberbullying lebih besar pada laki-laki. Selain itu, ditemukan bahwa dalam penelitian mengenai perilaku cyberbullying (dalam Navarro, 2016) pada 5789 remaja dari enam negara termasuk Canada dan Spanyol menemukan bahwa laki-laki (46.8 \%) lebih banyak melakukan cyberbullying dibanding perempuan $(31.7 \%)$.

Jika ditinjau berdasarkan gender, cyberbullying banyak terjadi pada perempuan. Hal tersebut dbuktikan melalui penelitian yang dilakukan oleh Hinduja dan Patchin (2017) dari tahun 2004-2016, menemukan bahwa perempuan lebih sering menjadi korban cyberbullying daripada anak laki-laki. Jenis cyberbullying yang terjadi kepada anak perempuan lebih cenderung mengatakan seseorang menyebarkan desas-desus tentang 
mereka secara online selain itu anak perempuan juga cenderung dilecehkan secara verbal oleh teman laki-laki mereka ataupun laki-laki yang mereka kenal dari media sosial. Komalasari, Eka, dan Wahyuni (2012) juga menemukan bahwa sebanyak $28 \%$ remaja perempuan di Jakarta mengalami cyberbullying melalui website. Berdasarkan penelitian lintas negara dan budaya di Eropa yang dilakukan terkait perilaku cyberbullying melalui self report terhadap 202.956 remaja yang berasal dari 40 negara di dunia, ditemukan bahwa 35\% bullying terjadi pada perempuan (Craig, et al., 2009). Bentuk cyberbullying yang terjadi pada perempuan adalah penindasan di dunia maya ketika pelaku mengirim konten seksual atau gambar-gambar porno, mengrimi kata-kata yang tidak senonoh dan difitnah (dalam Navarro, 2016). Adapun kasus cyberbullying yang terjadi pada remaja perempuan di Indonesia berdasarkan data dari Komnas Perlindungan Perempuan adalah kasus kekerasan yang terjadi secara online dimana didominasi oleh kasus kekerasan di media sosial. cyberbullying terbanyak terjadi melalui pesan singkat yaitu $24 \%$, lalu 235 di Facebook, $21 \%$ di Instagram, $21 \%$ di Twitter dan $10 \%$ di Snapchat (Cahya, 2017).

Menurut Kirnandita (2017) fenomena perempuan yang menjadi korban cyberbullying juga ditemukan di Indonesia. Hal ini dikemukakan oleh Survey dari Jajak Pendapat Aplikasi (Jakpat) terhadap 512 responden wanita di Indonesia usia 16-45 tahun dimana ada sekitar $12,52 \%$ pengguna menyatakan pernah mengalami pelecehan verbal dan visual saat mengakses apliakasi kencan Tinder. Permintaan kencan, komentar dengan muatan seksual atau lawakan-lawakan jorok dan bahkan memperlihatkan gambar-gambar berkonten seksual tanpa diminta oleh perempuan tersebut juga menjadi hal yang sering didapatkan oleh perempuan di media sosial online.

Selain itu beberapa remaja perempuan biasanya mendapatkan pesan-pesan berkonten seksual tanpa persetujaun mereka. Lebih lanjut dijelaskan oleh Madigan, Ly, Rash, Outysel, dan Temple (2018) yang melakukan penelitian pada 110.380 remaja yang berusia 12-17 tahun dimana ditemukan bahwa remaja perempuan melaporkan telah dikirimi pesan dengan konten seksual, atau dipaksa mengirimkan gambar atau video dengan konten sexual. Namun dampak apabila perempuan mengirimkan gambar atau video ke pelaku maka pelaku terkadang membagikan video dan gambar tersebut ke ranah publik untuk mempermalukan korban. Perempuan juga sering ditekan untuk bertemu dengan pelaku untuk melakukan hubungan seksual. Penelitian tersebut juga menyatakan bahwa $12,5 \%$ remaja mengaku bahwa foto mesranya disebarluaskan oleh orang lain tanpa sepengetahuannya dan lebih dari $40 \%$ mengatakan bahwa pelecehan online membuat mereka khawatir terhadap keamanan fisik mereka, stres dan menjadi kesulitan tidur, serta kehilangan kepercayaan diri dan membuat mereka menjadi sering panik pasca kejadian tersebut (Madigan et al., 2018). Hal tersebut merupakan salah satu contoh manifestasi dari adanya faktor peran gender yang terlibat dalam kasus cyberbullying pada remaja perempuan di internet khususnya pada aplikasi kencan online dan interaksi di media sosial.

Dehue (2013) mendefinisikan cyberbullying sebagai perilaku berulang yang agresif, menyakiti dan bermaksud untuk menyebabkan kerusakan yang diakibatkan ketidakseimbangan kekuatan. Cyberbullying juga dapat diartikan sebagai agresi yang sengaja dilakuan berulang kali melalui internet atau menggunakan perangkat elektronik terhadap seseorang yang tidak dapat melindungi dirinya sendiri (Kowalski, Morgan, \& Limber, 2012) sedangkan, Lenhart (2015) menjelaskan bahwa cyberbullying merupakan istilah yang digunakan saat seorang remaja mendapat tindakan tidak menyenangkan seperti dihina, diancam, dipermalukan, disiksa atau menjadi target bulan-bulanan oleh remaja lain dengan menggunakan teknologi internet, teknologi digital interkatif maupun teknologi mobile. Dampak yang ditimbulkan oleh cyberbullying hampir sama buruknya dengan bentuk bullying fisik. Gradinger, Strohmeier, \& Spiel (dalam 
Safaria, 2016) mengemukakan bahwa korban bullying dan cyberbullying menunjukkan penyesuaian diri yang buruk, depresi, agresi dan gejala somatik lainnya dibandingkan dengan siswa yang tidak mengalami bullying. Korban cyberbullying juga dikaitkan dengan masalah sosial dan depresi yang signifikan secara klinis, masalah akademis dan bolos sekolah, (Patchin \& Hinduja, 2017).

Menurut Kowalski (dalam Kowalski, Limber \& Agatston, 2012) ada tujuh kategori tindakan cyberbullying, yaitu: (a) flaming, (b) harassment, (c) cyberstalking, (d) denigration, (e) impersonation, (f) outing dan trickery, ( $g$ ) exclusion. Flaming didefinisikan sebagai tindakan mengirimkan pesan yang bersifat vulgar dan mengungkapkan kemarahannya kepada seseorang melalui grup online atau chat pribadi melalui media sosial seperti $e$-mail, sms dan lainnya. Harassment didefinisikan sebagai perilaku yang dilakukan oleh pelaku dengan mengirimkan pesan yang bersifat menyerang dan tidak pantas kepada korbannya secara berulang kali. Cyberstalking didefinisikan sebagai perilaku mengganggu terus menerus dan mengancam korban dengan pesan. Denigration didefinisikan sebagai perilaku yang dengan sengaja membuat informasi yang tidak sesuai kenyataan dan pernyataan yang kejam mengenai korban yang kemudian diunggah dan disebarluaskan lewat media sosial. Impersonation didefinisikan sebagai perilaku dimana pelaku berpura-pura menjadi korban dan mengirimkan sesuatu sehingga terlihat buruk. Outing dan trickery didefinisikan sebagai perilaku membujuk atau menipu korban untuk mengungkapkan rahasia pribadinya. Exclusion didefinisikan sebagai perilaku mengeluarkan seseorang secara sengaja dari kelompok.

Menurut Patchin dan Hinduja (2017), remaja yang melakukan cyberbullying adalah remaja yang memiliki harga diri rendah. Remaja tersebut hanya mementingkan dirinya sendiri dibanding orang lain sehingga menganggap orang lain tidak ada artinya. Oleh karena itu pelaku cyberbullying merasa bahwa mengejek dan menghina menjadi sangat menyenangkan bagi dirinya tetapi tidak dengan yang dirasakan oleh korban. Menurut Mesch (2009), cyberbullying dapat terjadi karena adanya masalah dalam berinteraksi (iri dan kurang toleran), pengalaman kejahatan sehingga menimbulkan dampak negatif bagi pelaku, dan kebiasaan yang dilakukan saat di sekolah. Sedangkan menurut Hoff dan Mitchel (2009) ada beberapa alasan remaja melakukan cyberbullying kepada orang yang tidak disukainya, salah satunya adalah karena kurangnya toleransi. Allport (dalam Zuma, 2014) dalam bukunya Nature of Prejudice menjelaskan bahwa akar dari sifat tidak toleransi adalah adanya prasangka kepada orang lain. Prasangka membuat remaja yang melakukan cyberbullying merasa dirinya lebih baik daripada orang lain yang ia bully.

Menurut Taylor, Peplau, dan Sears (2012) prasangka merupakan evaluasi negatif atas suatu kelompok atau seseorang berdasarkan pada keanggotaan orang itu dalam suatu kelompok. Myers dan Twenge (2017) menjelaskan bahwa prasangka dapat dikategorikan menjadi tiga jenis, yaitu prasangka ras, prasangka gender dan prasangka terhadap hubungan gay-lesbian. Prasangka gender, menjelaskan tentang kepercayaan orang-orang tentang bagaimana seharusnya laki-laki dan perempuan berperilaku. Prasangka yang berhubungan dengan gender dipengaruhi oleh rasisme dan sexisme. Sexisme adalah sikap prasangka individu dan perilaku diskriminasi yang diberikan kepada seseorang berdasarkan jenis kelamin atau praktek-praktek yang dilakukan oleh lembaga atau suatu instutsi berdasarkan jenis kelamin seseorang. Prasangka gender juga disebabkan oleh stereotipe seseorang terhadap perempuan. Senter (Myers $\&$ Twenge, 2017) juga menjelaskan dalam penelitiannya bahwa stereotipe terhadap gender lebih kuat daripada stereotipe terhadap ras.

Prasangka gender dalam hal ini sikap sexisme didefinisikan sebagai pandangan permusuhan dari hubungan gender dimana perempuan dianggap berupaya untuk 
megendalikan laki-laki dan merebut kekuasaan laki-laki. Namun di sisi yang lain, perempuan juga dipandang sebagai gender yang lemah yang membutuhkan laki-laki dan hanya cocok untuk melakukan peran gender konvensional seperti ibu rumah tangga (Rollero, Glick \& Tartaglia, 2014). Lebih lanjut Leaper dan Brown (2017) menjelaskan bahwa sikap ini meliputi keyakinan umum atau kognisi tentang individu berdasarkan kategori atau ekspresi gender mereka seperti misalnya perempuanperempuan suka boneka. Ketika keyakinan umum mempengaruhi emosi, reaksi, dan perilaku individu maka sexisme dapat terjadi dalam bentuk prasangka dan diskriminasi berbasis gender. Prasangka dan diskriminasi ini terjadi apabila streotipe terhadap gender yang dimiliki masyarakat dilanggar atau diluar ekspekstasi mereka misalnya 'sepakbola adalah permainan yang baik untuk laki-laki tapi tidak untuk perempuan', dampak dari keyakinan ini adalah perempuan yang bermain bola akan cenderung dianggap tomboy atau galak sedangkan laki-laki yang tidak menyukai sepak bola dianggap kurang maskulin.

Salah satu teori mengenai seksisme adalah teori seksisme ambivalen (Glick \& Fiske, 1996) yang menyatakan bahwa seksisme terdiri dari dua ideologi yang berbeda namun saling melengkapi. Ideologi ini merupakan aspek dasar dari seksisme yaitu : (a) Hostile Sexism, (b) Benevolent Sexism. Hostile Sexism didefinisikan sebagai sikap permusuhan terhadap perempuan. Perempuan dilihat sebagai berusaha untuk merebut kekuasaan laki-laki dengan berbagai cara, misalnya melalui seksualitas, dengan mengklaim diri mereka sebagai korban diskriminasi, atau melalui kegiatan aktivisme feminis. Benevolent sexism didefinisikan sebagai sikap positif, di mana perempuan dicirikan sebagai individu yang seharusnya menjadi penerima perlindungan, idealisasi, dan kasih sayang laki-laki.

Pelecehan dan kekerasan terhadap perempuan disebabkan karena adanya pandangan yang mengasosiasikan perempuan sebagai objek laki-laki (Myers \& Twenge, 2017). Di Indonesia sendiri kasus pelecehan dan kekerasan termasuk dalam kategori yang tinggi. Dari hasil pencatatan Komnas Perempuan terdapat 321.752 kasus kekerasan yang terjadi sepanjang tahun 2015. Angka tersebut naik sebanyak $9 \%$ dibanding tahun 2014. Dari ratusan ribu kasus tersebut sebanyak $38 \%$ merupakan kasus kekerasan fisik dan 3.325 kasus merupakan kekerasan seksual (Hamdoni, 2017). Beberapa bully yang terjadi pada perempuan di masyarakat dan media sosial juga berkaitan dengan sikap sexisme yang ada di masyarakat khususnya pada kasus pemerkosaan. Hal ini dikarenakan dampak lain dari adanya sikap sexisme di masyarakat adalah adanya victim blaming terhadap korban pemerkosaan atau dengan kata lain masyarakat Indonesia masih banyak yang suka memberikan stigma kepada korban pemerkosaan dan lebih parahnya menyalahkan korban pemerkosaan. Korban seringkali dianggap bersalah dan beberapa oknum cenderung menganggap lumrah perilaku asusila yang dilakukan oleh pelaku. Menurut Uli Pangaribuan (dalam Aprillatu, 2015) selaku Divisi Pelayanan Hukum-Asosiasi perempuan Indonesia stigma pada masyarakat masih menganggap bahwa korban pemerkosaan itu genit dan bahkan beberapa penyidik di kepolisian cenderung memandang sebelah mata jika ada korban yang melaporkan apalagi jika mengetahui korban sudah tidak perawan.

Selain itu, beberapa penelitian juga menunjukkan bahwa kekerasan terhadap perempuan tidak hanya terjadi di dunia nyata. Melainkan juga terjadi di dunia maya. Bedanya adalah kekerasan yang diterima oleh perempuan di dunia maya adalah kekerasan verbal. Hal tersebut dbuktikan melalui penelitian yang dilakukan oleh Hinduja dan Patchin (2017) dari tahun 2004-2016, menemukan bahwa perempuan lebih sering menjadi korban cyberbullying daripada anak laki-laki. Jenis cyberbullying cenderung berbeda berdasarkan gender; anak perempuan lebih cenderung mengatakan seseorang menyebarkan desas-desus tentang mereka secara online sementara anak laki-laki lebih cenderung mengatakan bahwa seseorang 
mengancam akan menyakiti mereka secara online. Komalasari, Eka, dan Wahyuni (2012) juga menemukan bahwa sebanyak $28 \%$ remaja perempuan di Jakarta mengalami cyberbullying melalui website dibanding laki-laki yang hanya $17 \%$. Berdasarkan penelitian lintas negara dan budaya di Eropa yang dilakukan terkait perilaku cyberbullying melalui self report terhadap 202.956 remaja yang berasal dari 40 negara di dunia, ditemukan bahwa $35 \%$ bullying terjadi pada perempuan (Komalasari, Eka, dan Wahyuni, 2012).

Berdasarkan fenomena diatas, dapat dikatakan bahwa prasangka suatu individu terhadap gender dapat membuat mereka melakukan perbuatan yang tidak menyenangkan kepada orang lain seperti cyberbullying. Selain itu harga diri juga dapat berkontribusi terhadap cyberbullying yang dilakukan remaja. Berdasarkan survei juga diketahui bahwa pada usia remaja khususnya pelajar SMA sederajat tingkat kasus cyberbullying cukup tinggi. Namun, sejauh ini belum ada penelitian yang membahas tentang hubungan harga diri dan prasangka gender dengan perilaku cyberbullying khususnya di daerah Jakarta. Oleh sebab itu, peneliti tertarik untuk mengetahui bagaimana hubungan harga diri dan prasangka gender dengan kecenderungan perilaku cyberbullying pada pelajar di Jakarta.

\section{METODE}

Variabel terikat dalam penelitian ini adalah kecenderungan perilaku cyberbullying dan variabel bebas dalam penelitian ini terdiri atas harga diri dan prasangka gender. Karakteristik responden dalam penelitian ini pelajar SMA dan SMK atau sederajat yang berusia 15-19 tahun, bersekolah di Jakarta, memiliki akun media sosial, mempunyai alat komunikasi dan internet, mengakses media sosial minimal 6 bulan terakhir. Berdasarkan hasil pengumpulan data yang dilakukan oleh peneliti dengan menggunakan kuesioner online pada pelajar yang bersekolah di SMA disekitar Jakarta utara, Jakarta Barat, Jakarta Pusat, Jakarta Selatan, dan Jakarta timur. didapatkan partisipan sebanyak 435 orang responden yang terdiri atas 142 orang laki-laki $(32,6 \%)$ dan 293 orang perempuan $(67,4 \%)$.

Dalam penelitian ini, peneliti mengukur harga diri menggunakan alat ukur Rosenberg self-esteem scale yang telah diterjemahkan dan diadaptasi oleh peneliti. Skala ini merupakan skala likert $1-5$ yang terdiri atas 10 butir yang mengukur tingkat harga diri individu. Pernyataan harus dijawab dengan memilih salah satu dari pernyataan Sangat Tidak setuju (STS), Tidak setuju (TS), Ragu-ragu (RR), Setuju (S), Sangat setuju (SS). Penilaian menggunakan skala likert dimana nilai untuk Sangat tidak setuju $=1$, Tidak Setuju $=2$, Ragu-ragu $=3$, Setuju $=4$, Sangat Setuju $=5$. Peneliti menguji reliabilitas alat ukur dalam penelitian ini dengan menggunakan 30 sampel remaja SMA sederajat di Jakarta. Berdasarkan hasil uji reliabilitas alat ukur menggunakan data try out didapatkan cronbach alpha yang cukup baik pada alat ukur harga diri yaitu sebesar 0,753 .

Peneliti mengukur prasangka terhadap gender menggunakan alat ukur Short Version Ambivalent Sexism Inventory milik Rollero, Glick, dan Tartaglia (2014) yang telah diterjemahkan dan diadaptasi oleh peneliti. Skala ini merupakan skala likert 1-5 yang terdiri atas 12 butir yang mengukur dua aspek dari prasangka gender yaitu hostile sexism dan benevolent sexism. Pernyataan harus dijawab dengan memilih salah satu dari pernyataan Sangat Tidak setuju (STS), Tidak setuju (TS), Ragu-ragu (RR), Setuju (S), Sangat setuju (SS). Penilaian menggunakan skala likert dimana nilai untuk Sangat tidak setuju $=1$, Tidak Setuju $=2$, Ragu-ragu $=3$, Setuju $=4$, Sangat Setuju $=5$. Dari hasil tryout yang telah dilakukan, peneliti menemukan bahwa reliabilitas pada dimensi Hostile Sexism (HS) sebesar 0,722 sedangkan pada reliabilitas Benevolence Sexism (BS) sebesar 0,635. Reliabilitas alat ukur secara keseluruhan memiliki cronbach alpha sebesar 0,706. Dengan demikian, alat ukur prasangka gender 
memiliki cronbach alpha yang masih cukup baik.

Sementara itu, perilaku cyberbullying diukur oleh peneliti menggunakan alat ukur Revised-Cyberbullying Inventory II milik Topcu dan Baker (2010) yang diterjemahkan oleh peneliti. Skala ini merupakan skala likert 1-4 yang terdiri atas 12 butir yang mengukur 6 aspek dari kecenderungan perilaku cyberbullying yaitu flaming, harassment, cyberstalking denigration, impersonation, outing and trickery Penilalian menggunakan skala Likert dengan memilih pernyataan tidak pernah, sekali, 2-3 kali, dan lebih dari 3 kali. Dimana nilai untuk tidak pernah $=1$, sekali $=2$, 2-3 kali $=3$, lebih dari 3 kali $=4$. Reliabilitas alat ukur yang peneliti dapatkan dari hasil try out menunjukkan angka sebesar 0,760 dan hasil ini menunjukkan reliabilitas yang cukup baik untuk dipakai.

Sebelum melakukan analisa data, uji normalitas dilakukan terlebih dahulu. Nisfiannoor (2009) menjelaskan uji normalitas dilakukan untuk mengetahui apakah distribusi sebuah data yang didapatkan mengikuti atau mendekati hukum sebaran normal dari Gauss. Uji normalitas dalam penelitian ini menggunakan 1- Samples K-S. data normal bila nilai sig (p) > 0.05 akan digunakan korelasi pearson productmoment untuk melihat adanya hubungan antara variabel $\mathrm{x}$ dan variabel y dan apabila data tidak normal yaitu nilai sig (p) < 0.05 akan digunakan korelasi spearman untuk menentukan besarnya hubungan antara variabel $\mathrm{x}$ dan variabel $\mathrm{y}$. Kekuatan hubungan korelasi antara -1 sampai +1 . Apabila $r=-1$ artinya korelasi negatif sempurna, dimana variabel $\mathrm{x}$ dan variabel y saling bertolak belakang. Jika $\mathrm{r}=$ 1 maka korelasi positif sempurna artinya variabel $\mathrm{x}$ dan variabel y searah.

\section{HASIL PENELITIAN}

Tabel hasil analisis korelasi Spearman Rho menunjukkan sebagai berikut
Tabel 1. Hasil Analisis Korelasi Harga Diri dan Cyberbullying

\begin{tabular}{lrr}
\hline \multicolumn{3}{c}{ Correlations } \\
\hline $\begin{array}{l}\text { Spearman's } \\
\text { rho }\end{array}$ & Cyberbullying \\
& Harga diri Correlation & $-0.136^{* *}$ \\
& Coefficient & \\
& Sig (2-tailed) & 0.005 \\
$\mathrm{~N}$ & 435 \\
\hline
\end{tabular}

Tabel 2. Hasil Analisis Korelasi Prasangka Gender dan Cyberbullying

\begin{tabular}{|c|c|c|c|}
\hline \multicolumn{4}{|c|}{ Correlations } \\
\hline \multirow{5}{*}{$\begin{array}{l}\text { Spearman's } \\
\text { rho }\end{array}$} & & & Cyberbullying \\
\hline & Prasangk & Correlation & $0.128 * *$ \\
\hline & Gender & Coefficient & \\
\hline & & Sig (2-tailed) & 0.008 \\
\hline & & $\mathrm{N}$ & 435 \\
\hline
\end{tabular}

Tabel 3. Hasil Analisis Korelasi Benevolence Sexism (dimensi Prasangka Gender) dan Cyberbullying

\begin{tabular}{|c|c|c|}
\hline \multicolumn{3}{|c|}{ Correlations } \\
\hline Spearman's & & Cyberbullying \\
\hline \multirow[t]{4}{*}{ rho } & Benevolen Correlation & -0.063 \\
\hline & Coefficient & \\
\hline & Sig (2-tailed) & 0.188 \\
\hline & $\mathrm{N}$ & 435 \\
\hline
\end{tabular}

Tabel 4. Hasil Analisis Korelasi Hostile Sexism (dimensi Prasangka Gender) dan Cyberbullying

\begin{tabular}{|c|c|c|c|}
\hline \multicolumn{4}{|c|}{ Correlations } \\
\hline \multirow{5}{*}{$\begin{array}{l}\text { Spearman's } \\
\text { rho }\end{array}$} & & & Cyberbullying \\
\hline & Hostile & Correlation & $0.205 * *$ \\
\hline & & Coefficient & \\
\hline & & Sig (2-tailed) & 0.000 \\
\hline & & $\mathrm{N}$ & 435 \\
\hline
\end{tabular}

Analisis uji statistik non parametrik korelasi Spearman digunakan karena uji asumsi syarat normalitas data yang dilakukan tidak terpenuhi, sehingga peneliti tidak dapat menggunakan uji statistik parametrik korelasi Pearson. Hasil analisis menunjukkan bahwa harga diri dan cyberbullying memiliki hubungan yang signifikan dengan nilai $\mathrm{p}$ 0,005 $<0,01$ dengan nilai koefisien korelasi -0,136. Prasangka gender dan cyberbullying memiliki hubungan yang signifikan dengan nilai 0,008 < 0,01 dengan koefisien korelasi 0,128. Benevolence sexism dan cyberbullying tidak 
memiliki hubungan yang signifikan dengan nilai p 0,188 > 0,05 dengan koefisien korelasi 0,063. Hostile sexism dan cyberbullying memiliki hubungan yang siginifikan dengan nilai p $0,000<0,01$ dengan koefisien korelasi 0,205 .

Tabel hasil analisis deskriptif data tambahan gambaran tingkat harga diri dan kecenderungan cyberbullying menunjukkan sebagai berikut

Tabel 5. Gambaran Tingkat Harga Diri dan Cyberbullying

\begin{tabular}{ccc}
\hline Variabel & Mean & Kategori \\
\hline Harga diri & 3.55 & Tinggi \\
Cyberbullying & 1.40 & Rendah \\
\hline
\end{tabular}

Nilai harga diri memiliki mean empirik sebesar 3,55 dengan skala 1-5 maka nilai mean hipotetik adalah 3 dan nilai mean empirik yang lebih besar dari mean hipotetik menunjukkan bahwa rata-rata harga diri partisipan cenderung tinggi. Dengan kata lain, partisipan dalam penelitian ini cenderung memiliki harga diri yang tinggi dan memiliki penilaian yang baik terhadap dirinya sendiri. Nilai kecenderungan cyberbullying memiliki mean empirik sebesar 1,40 dengan skala 1-4 maka nilai mean hipotetik adalah 2,5 dan nilai mean empirik yang lebih kecil dari mean hipotetik menunjukkan bahwa rata-rata kecenderungan cyberbullying partisipan cenderung rendah. Dengan kata lain partisipan dalam penelitian ini memiliki tingkat kecenderungan perilaku cyberbullying yang rendah dan cenderung kurang melakukan bullying dalam dunia digital.

\section{DISKUSI}

Tujuan dari penelitian ini adalah untuk melihat hubungan antara harga diri dan prasangka gender dengan kecenderungan perilaku cyberbullying siswa SMA dan SMK sederajat di Jakarta. Maka dapat dijelaskan hasil penelitian ini menunjukkan bahwa harga diri memiliki hubungan negatif yang signifikan dengan kecenderungan perilaku cyberbullying artinya semakin tinggi harga diri seseorang maka semakin rendah kecenderungan perilaku cyberbullying. Namun sebaliknya dapat terjadi, yaitu jika harga diri yang dimiliki rendah maka kecenderungan untuk melakukan perilaku cyberbullying dapat menjadi tinggi. Hasil penelitian ini sejalan dengan hasil penelitian Patchin dan Hinduja (2010) yang menemukan bahwa pelaku cyberbullying cenderung memiliki harga diri yang rendah. Selain itu berdasarkan hasil penelitian Frisen, Jonsson, dan Persson (2007), penyebab pelaku bullying melakukan bullying kepada korbannya salah satunya adalah karena pelaku bullying sendiri tidak cukup memiliki harga diri yang baik sehingga mereka merasa perlu melakukan bullying agar dapat melindungi harga dirinya.

Berdasarkan hasil penelitian diketahui prasangka gender memiliki hubungan positif yang siginifikan dengan kecenderungan perilaku cyberbullying. Namun bila dilihat perdimensi maka yang memiliki hubungan signifikan dengan kecenderungan perilaku cyberbullying adalah dimensi hostile sexism. Hasil penelitian ini didukung oleh penelitian sebelumnya yang dilakukan oleh Pecino dan Duran (2016) yang menyatakan bahwa sikap permusuhan (hostile) atau prasangka negatif akan lebih memiliki hubungan dengan perilaku cyberbulllying yang dilakukan melalui mobile phone dan internet. Hal ini akan berbeda dengan sikap prasangka yang mendukung atau melindungi (benevolence) atau prasangka positif terhadap gender yang cenderung tidak merendahkan gender lain sehingga tidak terjadinya bullying. Dengan demikian semakin tinggi sikap permusuhan (hostile) yang dimiliki pada prasangka gendernya menunjukkan semakin tinggi pula perilaku cyberbulllying yang dilakukan. Sikap hostile sendiri didefinisikan sebagai sikap permusuhan dimana mencakup kepercayaan sebagai penyangkalan adanya diskriminasi, pertentangan dengan tuntutan yang dibuat oleh perempuan, dan kebencian terhadap kebijakan yang dibuat oleh perempuan, dan kebencian tentang kebijakan yang memberikan dukungan 
kepada wanita (Leaper dan Brown, 2017). Hasil ini sejalan dengan penelitian sebelumnya yang dilakukan oleh Abrams (dalam Pecino dan Duran 2016) tentang kekerasan laki-laki terhadap perempuan dalam bentuk ekspresi paling tradisional, di mana sikap permusuhan atau merendahkan perempuan merupakan sesuatu yang wajar untuk dilakukan. Sehingga semakin tingginya sikap prasangka gender yang negatif (hostile sexism) yang menganggap suatu permasalahan terjadi karena gender yang dimiliki akan memicu kecenderungan perilaku cyberbullying pada siswa.

Berdasarkan hasil penelitian diketahui bahwa responden dalam penelitian ini memiliki kecenderungan perilaku cyberbullying yang rendah. Hasil penelitian ini didukung oleh penelitian yang dilakukan oleh Komalasari, Wayuni dan Nabila (2012) pada remaja SMA Negeri di Jakarta yang mengatakan bahwa lebih dari $83 \%$ siswa menyatakan tidak pernah melakukan cyberbulllying baik melalui email, website, chat rooms, dan instant messaging. Penelitian lain yang mendukung hasil temuan yaitu hasil penelitian Schneider, O'Donnell, Stueve, dan Coulter (2012) yang meneliti remaja dengan rentang kelas 9-12 mengatakan bahwa hanya $15.8 \%$ siswa yang menyatakan melakukan cyberbulllying. Selain itu ada faktor yang menurut peneliti menjadi penyebab kategori perilaku cyberbulllying menjadi rendah. Hal tersebut kemungkinan disebabkan karena peneliti memberikan kuesioner yang sifatnya terbuka tanpa mengetahui apakah responden pernah melakukan cyberbulllying sebelumnya atau tidak sehingga pemberian kuesioner tersebut kurang terkontrol.

\section{SIMPULAN}

Berdasarkan hasil penelitian dengan menggunakan uji statistik non parametrik yaitu korelasi Spearman, didapatkan hasil bahwa terdapat hubungan yang signifikan antara harga diri dan prasangka gender terhadap kecenderungan perilaku cyberbullying. Bila dilihat perdimensi maka hostile sexism memiliki hubungan signifikan dengan kecenderungan perilaku cyberbullying sementara benevolence sexism tidak memiliki hubungan signifikan.

Berdasarkan penelitian yang telah dilakukan, maka peneliti menyarankan kepada tenaga pendidik agar memberikan sosialisasi dan seminar kepada para siswanya mengenai perilaku cyberbullying, dampak dan bagaimana cara menghadapinya serta mengajarkan kepada para siswa tentang bagaimana etika dalam melakukan interkasi di media sosial dengan baik agar kedepannya perilaku cyberbullying dapat diminalisir. Dalam penelitian ini peneliti menyadari masih terdapat beberapa kekurangan seperti jumlah sampel yang tidak merata antara perempuan dan laki-laki dimana jumlah lakilaki lebih banyak. Selain itu, karena kuesioner ini sifatnya terbuka maka kurang dapat terkontrol apakah orang yang menjadi responden dalam penelitian ini pernah melakukan cyberbullying atau tidak. Maka dari itu peneliti menyarankan untuk penelitian selanjutnya dengan topik serupa agar proporsi responden berdasarkan jenis kelamin dapat seimbang. Selain itu perlu juga dikontrol mengenai apakah responden sebelumnya pernah melakukan cyberbullying atau tidak. dan sebaiknya jumlah sampel ditambah. Selain itu isu cyberbullying dan prasangka gender ini dapat dikembangkan kedalam bentuk penelitian-penelitian lain dan melibatkan variabel yang lebih variatif misalnya menghubungkan perilaku cyberbullying dengan tindakan preventif seperti memberikan treatmen tertentu lalu untuk prasangka gender perlu dilakukan pengkajian lebih lanjut sehingga dapat ditemukan metode tertentu yang dapat diterapkan untuk meminimalisir dampak dari prasangka gender tersebut.

\section{DAFTAR PUSTAKA}

$\begin{gathered}\text { Aprillatu, P. D. (2015). Ketika } \\ \text { pemerkosaan justru dibilang } \\ \begin{array}{r}\text { genit. } \\ \text { dari }\end{array} \\ \text { hiunduh } \\ \text { https://www.merdeka.com/khas/ketika- }\end{gathered}$
kisah-kon-perkosaan-justru-dibilang-genit-


Cahya, K. D. (2017). Perempuan lebih khawatir 'cyber bullying' daripada pria. Diunduh dari https://lifestyle.kompas.com/read/2017/06 /28/134313720/perempuan.lebih.khawatir cyber.bullying.daripada.pria

Craig, W., Harel-Fisch, Y., Fogel-Grinvald, H., Dostaler, S., Hetland, J., Simons-Morton, B., ... HBSC Bullying Writing Group (2009). A cross-national profile of bullying and victimization among adolescents in 40 countries. International journal of public health, 54 Suppl 2(Suppl 2), 216-224. DOI:10.1007/s00038-0095413-9

Dehue, F. (2013). Cyberbullying research: New perspectives and alternative methodologies introduction to the special issue. Journal of Community \& Applied Social Psychology, 23(1), 1-6.

Frisen, A., Jonsson, A. K., Persson, C. (2007) Adolescents' perception of bullying: who is the victim? Who is the bully? What can be done to stop bullying. Adolescence. 42(168), 749-761.

Glick, P dan Fiske ,S,T. (1996). The Ambivalent Sexism Inventory: Differentiating Hostile and Benevolent Sexism, Journal of Personality and Social Psychology, 70(3), 491-512.

Hamdoni, H. (2017, April). Pawai Perempuan serukan 'hapus kekerasan dan diskriminasi' di Indonesia. BBC News Indonesia. Diunduh dari http://www.bbc.com/indonesia/indonesia39164947

Hoff, D. L., \& Mitchell, S. N. (2008, November). Cyberbullying: Causes, effect, and remedies. Journal of Educational Administration, 47(5), 652665.

DOI: https://doi.org/10.1108/09578230910981 107

Juwita, V. R., Kustanti, E. R. (2018). Hubungan Antara Pemaafan dengan Kesejahteraan Psikologis Pada Korban Perundungan. Jurnal Empati, 7(1), 274-282.
Kirnandita, P. (2017). Pelecehan verbal dan visual, sisi remang dunia kencan online. Diunduh dari https://tirto.id/pelecehanverbal-dan-visual-sisi-remang-duniakencan-online-ctrV

Komalasari, G., Nabilah, N., Wahyuni, E. (2012). Studi perilaku cyberbullying siswa sman di dki Jakarta. Insight: Jurnal Bimbingan dan Konseling, vol 1(1), 3-12. DOI: https://doi.org/10.21009/INSIGHT.011.0 $\underline{1}$

Kowalski, R.M., Limber, S.E., \& Agatston, P.W. (2012). Cyberbullying: Bullying in the digital age. Malden, MA: WileyBlackwell.

Kowalski, R, M., Morgan, C, A., Limber, S, P. (2012). Traditional bullying as a potential warning sign of cyberbullying. School Psychology International journal, 33(5), 505-519.

Laksana, B Alief. (2017). Mensos : 84\% anak usia 12-17 tahun mengalami bullying. Diunduh dari https://news.detik.com/berita/d3568407/mensos-84-anak-usia-12-17tahun-mengalami-bullying

Leaper, C., \& Brown, C. S. (2017). Sexism in Childhood and Adolesence : Recent Trends and Advances in Research. Journal of Child Development Perspectives,12 (1), 10-15. DOI: 10.1111/cdep.12247

Lenhart, A. (2015). Teens, social media \& Technology overview 2015. Diunduh dari http://www.pewinternet.org/2015/04/09/t eens-social media-technology-2015

Madigan S, Ly A, Rash CL, Van Ouytsel J, Temple JR. Prevalence of Multiple Forms of Sexting Behavior Among Youth: A Systematic Review and Metaanalysis. JAMA

Pediatr. 2018;172(4):327-335. doi:10.1001/jamapediatrics.2017.5314

Mesch, G. S. (2009). Parental mediation, online activities, and cyberbullying. Cyberpsychology \& Behavior: The 
Impact of The Internet, Multimedia, and Virtual Reality on Behavior and Society, 12 (4), 387-393. DOI: 10.1089/cpb.2009.0068

Myers, D. G. \& Twenge, J. M. (2017). Exploring social psychology $\left(8^{\text {th }}\right.$ ed). New York: McGrawHill Education.

Navarro R. (2016) Gender Issues and Cyberbullying in Children and Adolescents: From Gender Differences to Gender Identity Measures. In: Navarro R., Yubero S., Larrañaga E. (eds) Cyberbullying Across the Globe. Springer, Cham. DOI: https://doi.org/10.1007/978-3-319-2555212

Patchin, J. W., \& Hinduja, S. (2010). Cyberbullying and self-esteem. Journal of school health, 80(12), 614-621. DOI: 10.1111/j.1746-1561.2010.00548

Patchin, J.,W.,\& Hinduja, S. (2017). Digital self-harm among adolescents. Journal of Adolescent Health, 61(6), 761-766. DOI: https://doi.org/10.1016/j.jadohealth.2017. 06.012

Pecino, R, M., \& Duran,M. (2016). I love you but I cyberbully you : Role of Hostile sexism. Journal of Interpersonal Violence, 1-14.

Razak . N. (2014, Februari 18). Studi Terakhir: Kebanyakan Anak Indonesia sudah online, namun masih banyak yang tidak menyadari potensi resikonya. Diunduh dari

https://www.unicef.org/indonesia/id/medi a_22169.html

Rollero, C., Glick, P., Tartaglia, S. (2014). Psychometric properties of short versions of the ambivalent sexism inventory and ambivalence toward men inventory. The Journal Of Testing, Psychometric,
Methodology In Applied Psychology, 21 (2).49-159. DOI: 10.4473/TPM21.2.3

Rosenberg, M. (1965). Society and the adolescent self-image. Princeton, $\mathrm{NJ}$ : Princeton University Press.

Safaria, T. (2016). Prevalence and impact of cyberbullying in a sample of Indonesian junior high school students. The Turkish Online Journal of Educational Technology, 15(1), 82-91

Schneider, S. K., O'Donnell, L., Stueve, A., \& Coulter, R. W. (2012). Cyberbullying, school bullying, and psychological distress: a regional census of high school students. American journal of public health,102(1), 171-177. doi:10.2105/AJPH.2011.300308

Taylor, S, E.,Peplau, L, A.,Sears, D,O.(2012). Psikologi Sosial edisi Kedua Belas. Jakarta: Kencana Prenada Media Group.

Topcu, C., Baker, O, E. (2010). The revised cyber bullying inventory (RCBI): validity and reliability studies. Procedia and Behavioral science journal, 5(2010). 660664.

Wardani, D,M. (Juli 2016). 90 persen korban pemerkosaan di Indonesia bungkam. Satu Harapan. Diunduh dari http://www.satuharapan.com/readdetail/read/90-persen-korbanpemerkosaan-di-indonesia-bungkam

Zuma, B. (2014). Contact theory and the concept of prejudice: Metaphysical and moral explorations and an epistemological question. Theory \& Psychology, 24(1), 40-57. DOI: https://doi.org/10.1177/09593543135170 23 